\title{
PREVALENCE OF VIBRIO CHOLERAE AND VIBRIO SPECIES FROM DIFFERENT SOURCES IN BAYELSA STATE, NIGERIA
}

\author{
Michael Adetope Aladese* and Adenike Bosede Ariyo
}

Department of Biology Federal University Otuoke, Nigeria

Corresponding author E-mail: aladesema@gmail.com; Tel: +2348066417988

Cite this article:

Aladese M.A., Ariyo, A.B. (2021), Prevalence of Vibrio Cholerae and Vibrio Species from Different Sources in Bayelsa State, Nigeria. African Journal of Biology and Medical Research 4(2), 38-50. DOI:

10.52589/AJBMR-

G5ST3ZWT.

\section{Manuscript History}

Received: 30 March 2021

Accepted: 22 April 2021

Published: 3 May 2021

Copyright $\odot 2020$ The Author(s). This is an Open Access article distributed under the terms of Creative Commons AttributionNonCommercial-NoDerivatives 4.0 International (CC BY-NC-ND 4.0 ), which permits anyone to share, use, reproduce and redistribute in any medium, provided the original author and source are credited.
ABSTRACT: The distribution of Vibrio cholerae and noncholera Vibrio species from different sources from five localities in Bayelsa State, Nigeria was investigated in this study. A total of 44 stool samples, 22 freshwater samples, 60 brackish water samples and 64 seafood samples (crabs, shrimps and fishes) were collected from January to April, 2019 for the purpose of $V$. cholerae prevalence study. Samples were transported to the laboratory using Car-Blair's medium. This was followed by samples enrichment in $1 \%$ alkaline peptone water and pour plating on thiosulphate citrate bile-salt sucrose (TCBS) agar. Characteristic yellow colonies were subjected to further biochemical and physiological characterization to further identify $V$. cholerae. Antibiotics susceptibility patterns for isolated $V$. cholerae strains were investigated. Furthermore, water samples (fresh and brackish) and seafood samples were collected on a monthly basis to ascertain the effect of seasons (dry and wet months) on the distribution of Vibrio spp. A total of 16 (36.36\%) stools samples were positive for $V$. cholerae. In addition, 12 (54.55\%) of freshwater samples, 28 (46.67\%) of brackish water samples and 22 (34.38\%) of seafood samples were contaminated with $V$. cholerae. The monthly mean values of Vibrio spp. from environmental sources showed statistically significant difference $(P<0.05)$ between the dry months (low rainfall) and wet months (frequent rainfall). Higher average values were observed during the dry months. The result of the antibiotics sensitivity test showed all $V$. cholerae strains were susceptible to ciprofloxacin, ofloxacin and pefloxacin while varying degree sensitivities were observed in tetracycline and augmentin. Cholera and other non-cholera Vibrio spp gastrointestinal infections are still a major concern to the health of the public. Local and regional governments should enforce and promote the need for personal and communal hygienic practices.

KEYWORDS: Vibrio Cholerae, Vibrio Species, Bayelsa State, Nigeria 


\section{INTRODUCTION}

Vibrio cholerae is a potentially pathogenic Gram-negative bacterium. It is a facultatively anaerobic, oxidase positive and highly motile bacterium with the aid of polar flagellum. Regardless of a rich history of cholera with seven distinct pandemics since 1817 (Faruque et al., 1998), the bacterium is still relevant in public health in many settlements where safe drinking water is inadequate or absent.

The cholera vibrio is primarily a waterborne infection (Idika et al., 2000). The bacterium gets into the human system via faecal-oral route (Hutin et al., 2003). The cholera vibrio is able to evade the acidic conditions of the stomach through movement into the small intestine using its flagellum. Once inside the small intestine, the bacterium under appropriate environmental indices secretes an enterotoxin known as cholera toxin, which alters the host's physiology through the alteration of the adenylate cyclase enzyme system. This results in excessive release of water and electrolytes into the intestinal lumen. The resultant effect of this massive fluid loss is diarrhea and vomiting (Miller, 2003; Siddique et al., 1995).

The emergence of non-cholera Vibrio species associated with gastroenteritis is causing concerns to public health. Vibrio parahaemolyticus, which is a non-sucrose fermenting, oxidase positive and halophilic bacterium that could survive up to $6 \%$ salinity, is a prominent non-cholera Vibrio species with pathogenic potentials (Makino, 2003). Another non-cholera Vibrio species, V. vulnificus, infects humans through the ingestion of contaminated seafoods, mostly oysters (Miceli, 1993). V. mimicus is another non-cholera Vibrio species with epidemic potentials. This bacterium has been found to possess multiple copies of the ctx genetic element in its genome. This ctx genetic element is the lysogenic genome of the bacteriophage which confers toxigenic capabilities to Vibrio cholerae (Waldor \& Mekalanos, 1996; Waldor \& Raychaudhuri, 2000). Other non-cholera Vibrio spp are V. metschnikovii, V. fluvialis, V. hollisae and V. alginolyticus (Igbinosa et al., 2009; Elhadi et al., 2004; Rippey, 1994).

The prevalence of $V$. cholerae from different sources gives considerable information on the predisposing dangers. Also, the monthly prevalence of Vibrio spp generates indicative patterns of seasonal survival and persistence of these species from different environmental sources. The data obtained from the monthly distribution pattern of Vibrio spp is expected to give appreciable insights into the reasons cholera and other non-cholera Vibrio spp outbreaks are predominant in some months.

This study is aimed at the prevalence of $V$. cholerae from clinical and environmental samples from 5 (five) locations in Bayelsa State, South-South region of Nigeria. The study will also investigate the monthly distribution of total Vibrio spp counts in environmental samples to ascertain the seasonal effects on the survival and persistence of Vibrio species in fresh waters, brackish waters and seafoods. 


\section{MATERIALS AND METHODS}

\section{Study area}

Bayelsa State is geographically located at $4.45^{\circ} \mathrm{N}, 6.05^{\circ} \mathrm{E}$ and its name was derived from three major towns within the boundary of the state-Brass (BA), Yenagoa (YEL) and Sagbama (SA). Bayelsa State is located in the South-South region of Nigeria (Figure 1a) with eight (8) local government areas. There are four spoken dialects in the state which include: Izon, Nembe, Epie-Atissa and Ogbia. The primary occupations of most of the local populations in the suburban and rural communities are fishing, agriculture and brewing of local gins. Five locations were selected in Bayelsa State for this study; they are: Brass, Southern-Ijaw, Ogbia, Sagbama and Yenagoa (Figure 1b).

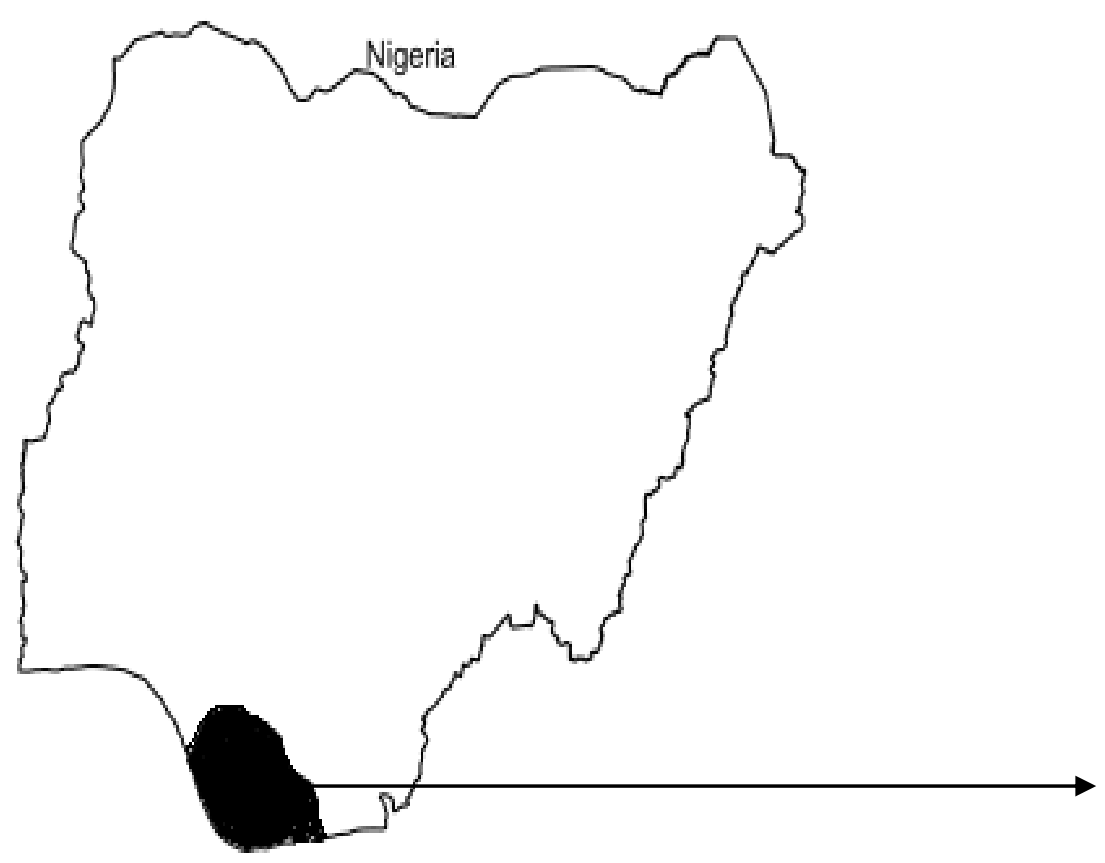

Figure 1a. Map of Nigeria showing the location of Bayelsa State. 


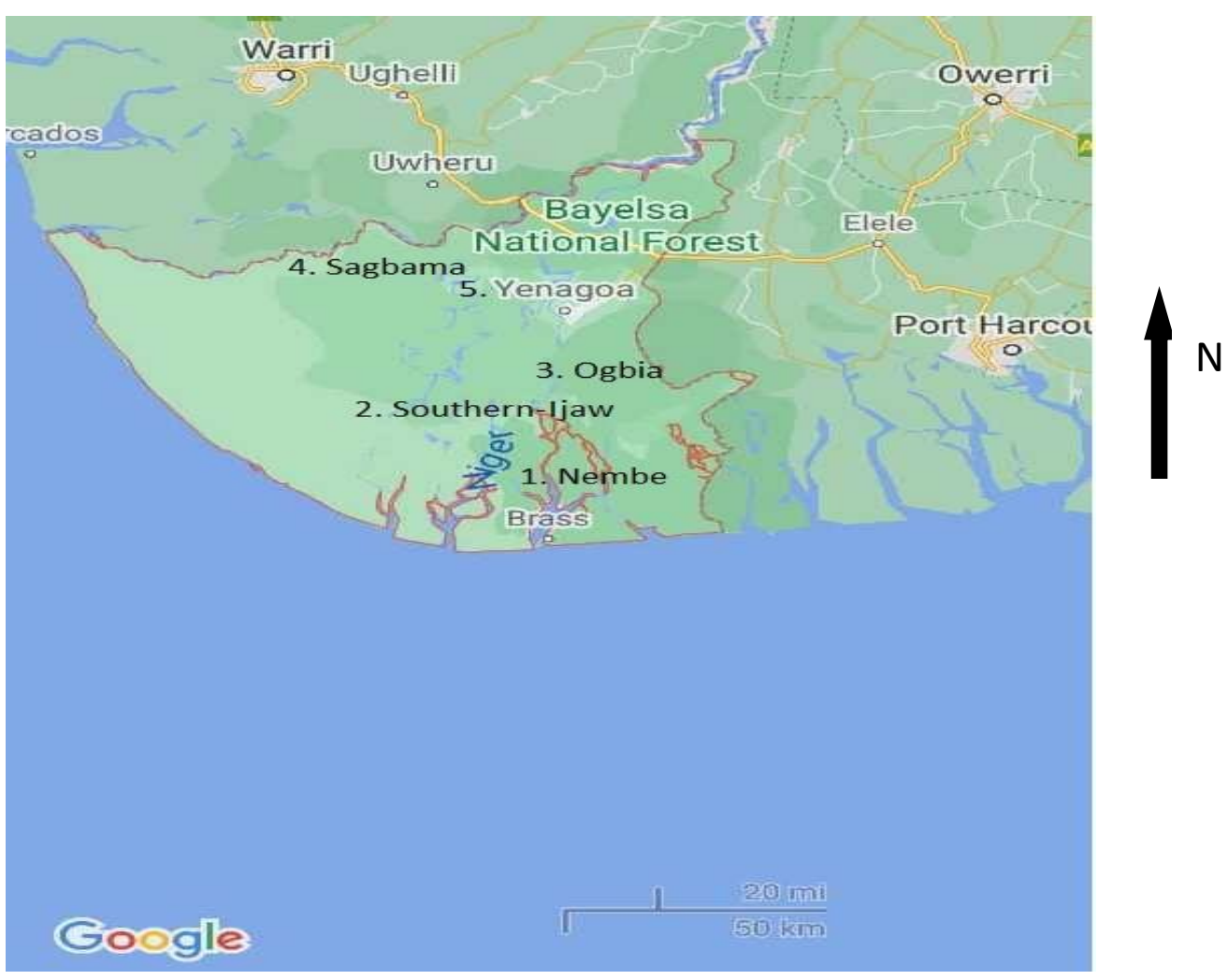

Figure 1b. Map of Bayelsa showing the selected localities of study.

Source: Google maps Inc.

\section{Clinical samples}

A total 44 stool samples were collected from January to April, 2019 from patients at the different primary health centres in Bayelsa. The samples were collected using sterile swabs sticks and inoculated into Cary-Blair medium for transport purposes.

\section{Water samples}

A total of 22 fresh water samples from wells and 60 brackish water samples, for the purpose of Vibrio cholerae detection, were collected between January and April, 2019 in different localities in Bayelsa State. The samples were inoculated into Cary-Blair medium for transport purposes.

\section{Seafood samples}

A total of 64 seafood samples were collected from major markets and in partnership with local fishermen in these localities. Samples were collected in sterile polythene bags, kept on ice and transferred to the laboratory for immediate analysis. Crabs were dissected and the chitinous external layers were discarded. Shrimps, fishes and the internal components of the dissected crabs were placed in a blender for grinding, to achieve homogenization. Samples were inoculated into $1 \%$ alkaline peptone water for enrichment purposes. Plating was then done on 
thiosulphate citrate bile-salt sucrose (TCBS) agar (Oxoid, England), using a pour plate method. Cultures were thereafter incubated at $37^{\circ} \mathrm{C}$ for $24 \mathrm{hrs}$.

\section{Enrichment and isolation of $V$. cholerae from clinical and water samples}

Clinical and water samples (fresh and brackish) from Cary-Blair medium were inoculated into $1 \%$ alkaline peptone water for enrichment purposes. They were plated out on thiosulphate citrate bile-salt sucrose (TCBS) agar (Oxoid, England) by the pour plate method and cultures were incubated at $37^{\circ} \mathrm{C}$ for $24 \mathrm{hrs}$. Characteristic yellow colonies were considered for further identification based on the methods described by Canada Communicable Disease Report (1998).

\section{Determination of viable plate count of Vibrio spp for samples}

Water samples and seafood were collected for the purpose of Vibrio species enumeration on a monthly basis from the selected settlements in this study, for the duration of 12 months. One millilitre each fresh and brackish water samples were serial diluted down to $10^{-6}$. From each water sample, $0.1 \mathrm{ml}$ and $1 \mathrm{~g}$ of homogenized tissue of seafoods were inoculated by pour plate method on a freshly prepared thiosulphate citrate bile-salt sucrose (TCBS) agar (Oxoid, England) plate at $37^{\circ} \mathrm{C}$ for $24 \mathrm{hrs}$. The plate was examined for characteristic Vibrio spp colonies and enumerated.

\section{Data representation}

All statistical calculations involving mean values, standard deviations, bar charts and pictorial representations were determined using the Microsoft Excel version 2016 and SPSS (version 23.0).

\section{RESULT}

The examination of clinical samples from patients for cholera bacterium showed highest prevalence in Southern-Ijaw with $75 \%$ of examined patients (table 1). All the freshwater samples were contaminated in Brass and Southern-Ijaw while Sagbama/Kaiama and Yenagoa did not show presence of $V$. cholerae (table 2). In the same vein, all the samples of brackish waters from Southern-Ijaw (100\%) were found to be contaminated with cholera vibrio (table 3 ). The distribution of $V$. cholerae from seafood showed highest prevalence in crabs with $40.91 \%$ of test samples with $V$. cholerae contamination (table 4 ). Table 5 shows the summary of prevalence of $V$. cholerae from all the sources. The highest percentage of occurrence was recorded in freshwater samples $(54.55 \%)$ followed by samples from brackish waters $(46.67 \%)$.

The average monthly distribution of Vibrio spp counts in freshwater samples from the different localities showed higher counts in the month of October to December and January to March (figure 2). Similarly, higher distribution of Vibrio spp counts were observed in the month of January to March and October to December, in samples of brackish waters (figure 3). The mean values of monthly distribution of Vibrio spp in crabs showed lower counts from the month of May to September (figure 4). The total viable Vibrio spp counts from shrimp samples had the lowest average values from the month of June to August (figure 5). Figure 6, which represents the mean monthly values of total Vibrio spp counts from fishes, showed lower distribution in 
African Journal of Biology and Medical Research

ISSN: 2689-534X

Volume 4, Issue 2, 2021 (pp. 38-50)

www.abjournals.org

the month of June to August. There are statistically significant differences $(\mathrm{P}<0.05)$ in the mean values of total Vibrio spp counts in months with recorded higher mean values.

The result of the antibiotics sensitivity patterns of $V$. cholerae showed all isolated strains were susceptible to the actions of ciprofloxacin, pefloxacin and ofloxacin while tetracycline, cotrimoxazole and augmentin showed different ranges of efficacies on isolated strains.

Table 1. Distribution of pathogenic Vibrio cholerae isolated in patients from different localities in Bayelsa State.

\begin{tabular}{|l|c|c|}
\hline \multicolumn{1}{l}{ Localities } & $\begin{array}{c}\text { Total numbers of patients } \\
\text { examined }\end{array}$ & Number of patients with cholera \\
\hline Nembe/Brass & 7 & $3(42.86)$ \\
\hline Southern Ijaw & 12 & $9(75.00)$ \\
\hline Ogbia & 10 & $4(40.00)$ \\
\hline Sagbama/Kaiama & 7 & $0(0.00)$ \\
\hline Yenagoa & 8 & $0(0.00)$ \\
\hline Total & 44 & $16(36.36)$ \\
\hline
\end{tabular}

*Numbers in parenthesis represents percentages of the positive cases of the test numbers

Table 2. Distribution of Vibrio cholerae isolated from freshwater in different localities in Bayelsa State, Nigeria

\begin{tabular}{|l|c|c|}
\hline \multicolumn{1}{l}{ Localities } & $\begin{array}{c}\text { Total numbers of fresh } \\
\text { examined }\end{array}$ & Number of wells with V. cholerae \\
\hline Brass & 3 & $3(100.00)$ \\
\hline Southern Ijaw & 3 & $3(100.00)$ \\
\hline Ogbia & 7 & $6(85.71)$ \\
\hline Sagbama/Kaiama & 4 & $0(0.00)$ \\
\hline Yenagoa & 5 & $0(0.00)$ \\
\hline Total & 22 & $12(54.55)$ \\
\hline
\end{tabular}

* Numbers in parenthesis represents percentages of the examined cases of the test numbers in each locality

Table 3. Distribution of Vibrio cholerae isolated from brackish waters in different localities in Bayelsa State, Nigeria

\begin{tabular}{|l|c|c|}
\hline \multicolumn{1}{l}{ Localities } & $\begin{array}{c}\text { Total numbers of brackish } \\
\text { waters examined }\end{array}$ & $\begin{array}{c}\text { Number of brackish waters with } \\
\text { V. cholerae }\end{array}$ \\
\hline Brass & 12 & $4(33.33)$ \\
\hline Southern Ijaw & 12 & $12(100.00)$ \\
\hline Ogbia & 12 & $8(66.67)$ \\
\hline Sagbama/Kaiama & 12 & $0(0.00)$ \\
\hline Yenagoa & 12 & $4(33.33)$ \\
\hline Total & 60 & $28(46.67)$ \\
\hline
\end{tabular}

*Numbers in parenthesis represents percentages of the examined cases of the test numbers in each locality 
Table 4. Distribution of Vibrio cholerae isolated from seafood in Bayelsa State

\begin{tabular}{|l|c|c|}
\hline Seafood & $\begin{array}{c}\text { Total numbers of seafood } \\
\text { samples examined }\end{array}$ & $\begin{array}{c}\text { Number of seafood samples } \\
\text { with } \boldsymbol{V} \text {. cholerae }\end{array}$ \\
\hline Crabs & 22 & $9(40.91)$ \\
\hline Shrimps & 18 & $6(33.33)$ \\
\hline Fishes & 24 & $7(29.17)$ \\
\hline Total & 64 & $22(34.38)$ \\
\hline
\end{tabular}

*Numbers in parenthesis represents percentage of examined seafood samples

Table 5. Prevalence of Vibrio cholerae from different sources in selected localities in Rivers and Bayelsa State, Nigeria.

\begin{tabular}{|l|c|c|}
\hline Source & Number examined & Number positive for $\boldsymbol{V}$. cholerae \\
\hline Clinical & 44 & $16(36.36)$ \\
\hline Fresh Water & 22 & $12(54.55)$ \\
\hline Brackish & 60 & $28(46.67)$ \\
\hline Seafood & 64 & $22(34.38)$ \\
\hline Total & 190 & $78(41.05)$ \\
\hline
\end{tabular}

*Figure in parenthesis represents percentages

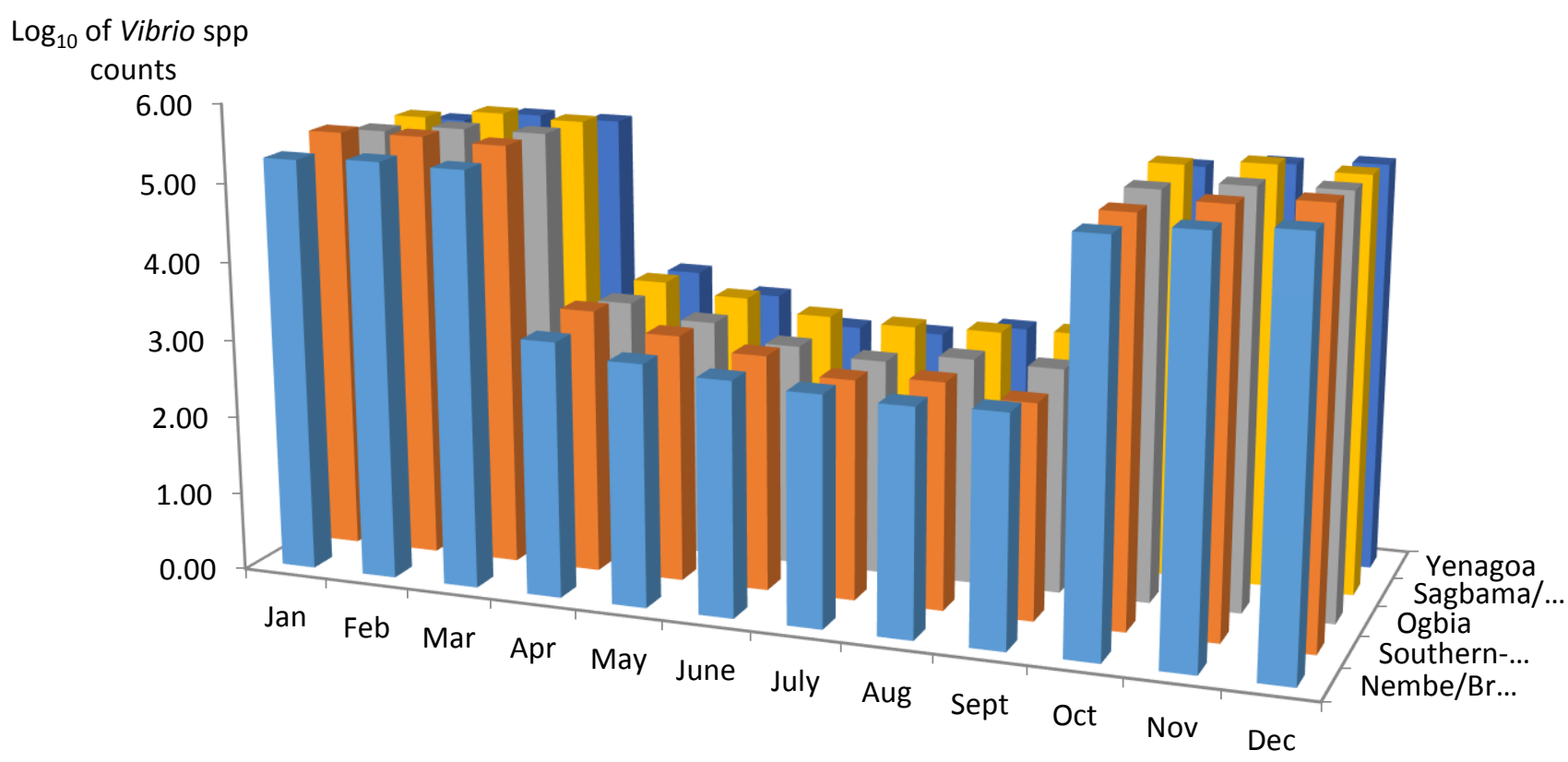

Figure 2: Average monthly distribution of Vibrio species counts in freshwater samples collected from different localities in Bayelsa State. 
African Journal of Biology and Medical Research

ISSN: 2689-534X

Volume 4, Issue 2, 2021 (pp. 38-50)

www.abjournals.org

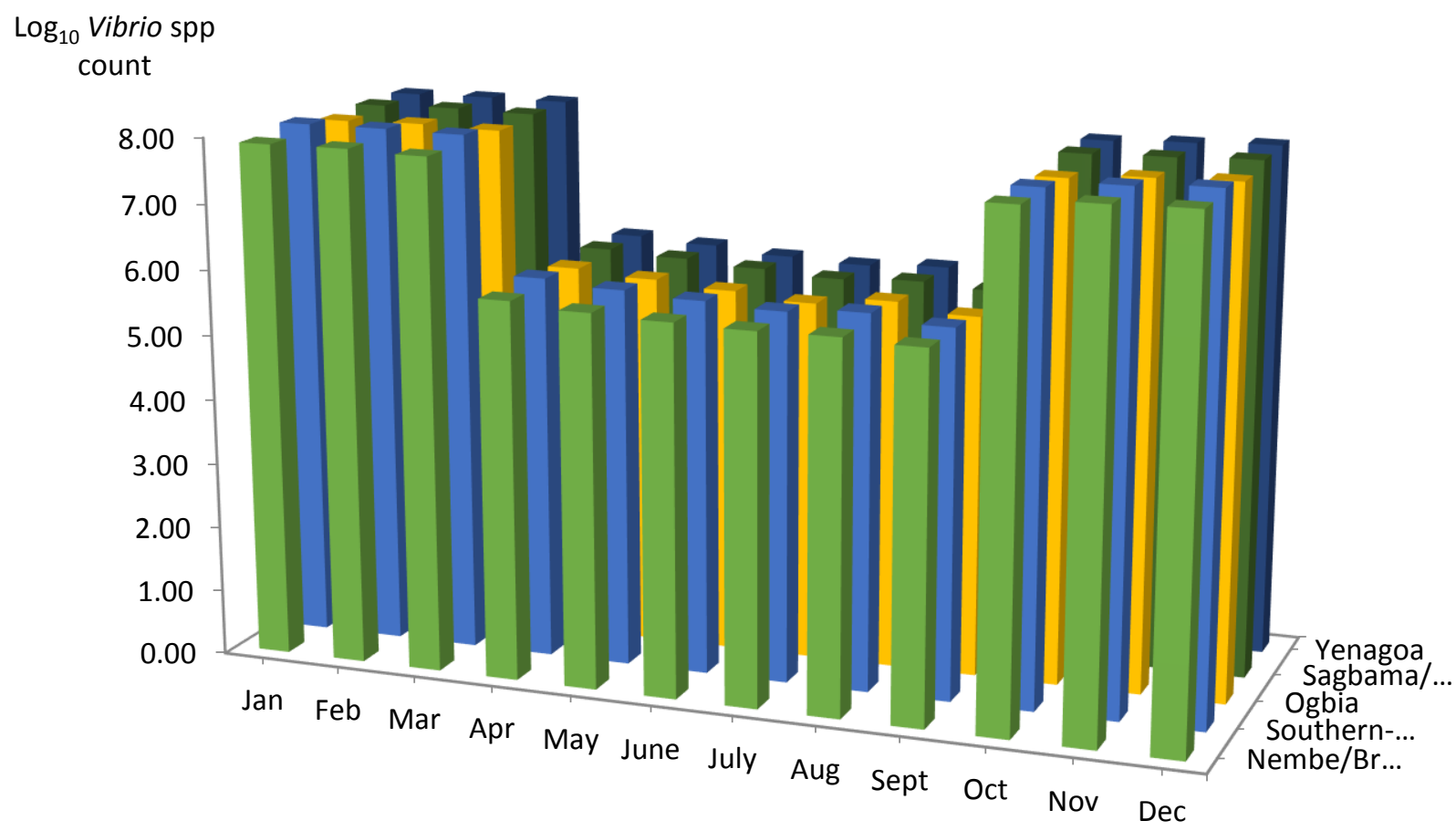

Figure 3: Average monthly distribution of Vibrio species counts in brackish water samples collected from different localities in Bayelsa State.

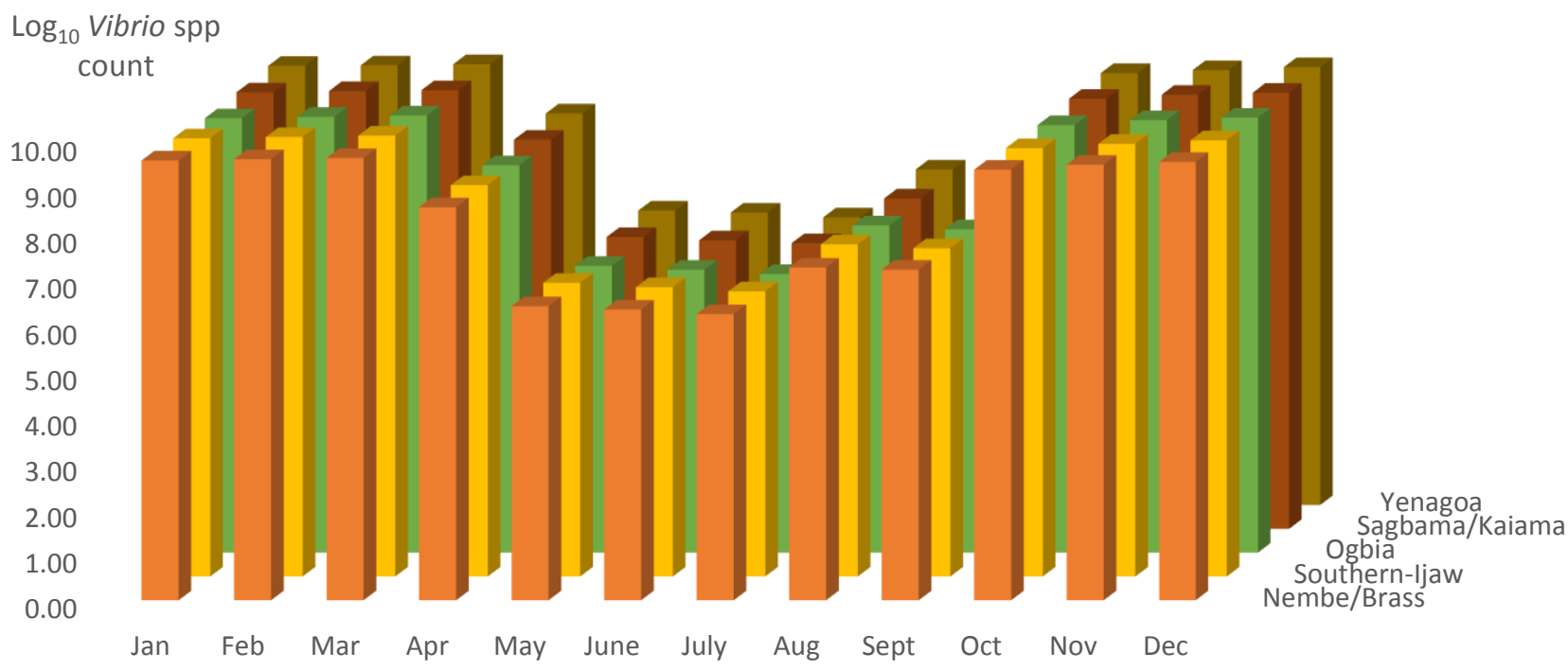

Figure 4: Average monthly distribution of Vibrio species counts in crabs from different localities in Bayelsa State. 
African Journal of Biology and Medical Research

ISSN: 2689-534X

Volume 4, Issue 2, 2021 (pp. 38-50)

www.abjournals.org

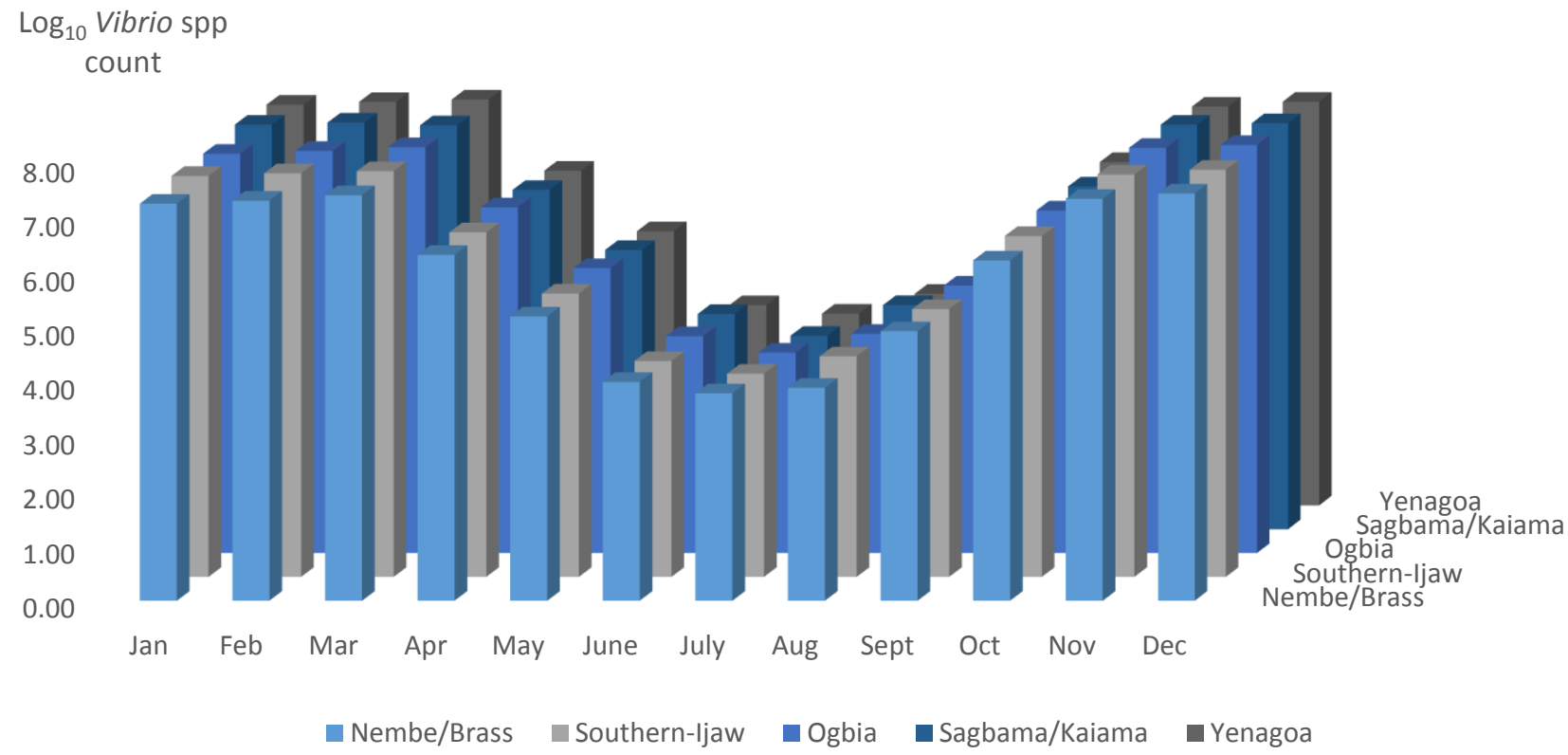

Figure 5: Average monthly distribution of Vibrio species counts in shrimps from different localities in Bayelsa State.

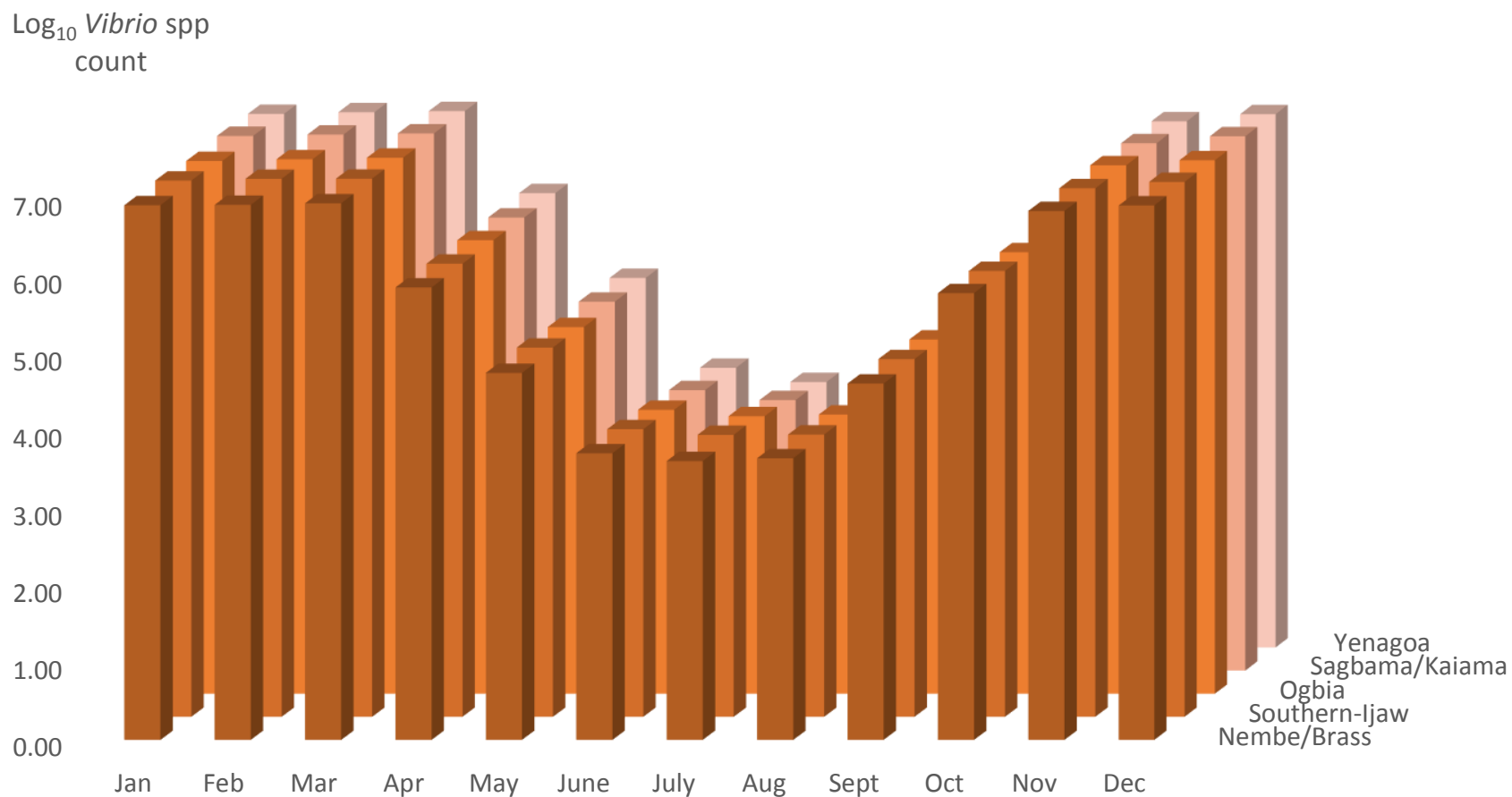

Figure 6: Average monthly distribution of Vibrio species counts in fishes from different localities in Bayelsa State. 
African Journal of Biology and Medical Research

ISSN: 2689-534X

Volume 4, Issue 2, 2021 (pp. 38-50)

www.abjournals.org

Table 6. Antibiotics susceptibility of Vibrio cholerae from different sources in Bayelsa State

\begin{tabular}{|l|l|l|l|l|l|l|l|l|}
\hline & \multicolumn{2}{|c|}{ Clinical } & \multicolumn{2}{c|}{ Fresh } & \multicolumn{2}{c|}{ Brackish } & \multicolumn{2}{|c|}{ Seafood } \\
\hline $\begin{array}{l}\text { Antibi } \\
\text { otics }\end{array}$ & $\begin{array}{l}\text { Numb } \\
\text { er } \\
\text { exami } \\
\text { ned }\end{array}$ & $\begin{array}{l}\text { Number of } \\
\text { sensitive } \\
\text { strains }\end{array}$ & $\begin{array}{l}\text { Numb } \\
\text { er } \\
\text { exami } \\
\text { ned }\end{array}$ & $\begin{array}{l}\text { Number of } \\
\text { sensitive } \\
\text { strains }\end{array}$ & $\begin{array}{l}\text { Numb } \\
\text { er } \\
\text { exami } \\
\text { ned }\end{array}$ & $\begin{array}{l}\text { Number of } \\
\text { sensitive } \\
\text { strains }\end{array}$ & $\begin{array}{l}\text { Numb } \\
\text { er } \\
\text { exami } \\
\text { ned }\end{array}$ & $\begin{array}{l}\text { Number of } \\
\text { sensitive } \\
\text { strains }\end{array}$ \\
\hline Amx & 44 & $29(65.91)$ & 22 & $15(68.18)$ & 60 & $37(61.67)$ & 64 & $41(64.06)$ \\
\hline Aug & 44 & $34(77.27)$ & 22 & $16(72.73)$ & 60 & $41(68.33)$ & 64 & $44(68.75)$ \\
\hline Cot & 44 & $32(72.73)$ & 22 & $14(63.64)$ & 60 & $39(65.00)$ & 64 & $42(65.63)$ \\
\hline Tet & 44 & $38(86.36)$ & 22 & $18(81.82)$ & 60 & $52(86.67)$ & 64 & $54(84.38)$ \\
\hline Pef & 44 & $44(100.00)$ & 22 & $22(100.00)$ & 60 & $60(100.00)$ & 64 & $64(100.00)$ \\
\hline Ofl & 44 & $44(100.00)$ & 22 & $22(100.00)$ & 60 & $60(100.00)$ & 64 & $64(100.00)$ \\
\hline Cpx & 44 & $44(100.00)$ & 22 & $22(100.00)$ & 60 & $60(100.00)$ & 64 & $64(100.00)$ \\
\hline
\end{tabular}

Amx $=$ Amoxicillin, Aug $=$ Augmentin, Cot $=$ Cotrimoxazole, Tet $=$ Tetracycline, Pef $=$ Pefloxacin, Ofl = Ofloxacin, Cip = Ciprofloxacin

\section{DISCUSSION}

The prevalence of pathogenic $V$. cholerae in patients from five (5) localities in this study (table 1) showed the highest percentage in patients from Southern-Ijaw (75\%). The distribution of $V$. cholerae in freshwater samples was high in Brass, Southern-Ijaw and Ogbia (table 2). Similarly, cholera bacterium was recovered from all examined brackish water samples in Southern-Ijaw (100\%) followed by Ogbia (table 3). The high percentage presence of $V$. cholerae in the water samples from these localities, especially Southern-ijaw, is expected. This could be attributed to the fact that there is an absence of effective sewage disposal system in many of these suburban creek settlements in Bayelsa State. The act of open defecation by local populations of these settlements, coupled with indiscriminate disposal of domestic wastes into water bodies, has been fingered as one of the predisposing epidemiological factors of infections and the resultant sporadic outbreaks in these communities. Aladese and Ariyo (2017) demonstrated a high correlation between indiscriminate disposal of human wastes and high microbial population in aquatic environments. Their assertion and our findings in this study further agree with other reported studies in the past (Edokayi, 2004; Onyema, 2011; Olorode et al., 2015).

The average monthly values of Vibrio spp counts $\left(\log _{10}\right)$ in freshwater samples (figure 2 ) showed a trend of lower mean values of prevalence in the months where rainfall is relatively higher. These months of profound increase in the amount of rainfall are collectively referred to as wet months or wet seasons of sub-Saharan tropical Africa. There is a statistically significant difference $(\mathrm{P}<0.05)$ in the mean values obtained in dry months and wet months. Similar trends were observed in the $\log _{10}$ values of Vibrio spp counts in brackish waters (figure 3 ). The reason for this trend could be as a result of increased discharge of freshwater into these surface waters during the wet seasons, due to increase in the amount of precipitation into the aquatic 
environments. This assertion is in concordance with past studies (Lawson, 2011; Amangabara \& Egenma, 2012).

The result of the monthly mean values of Vibrio spp counts $\left(\log _{10}\right)$ in crabs (figure 4), shrimps (figure 5) and fishes (figure 6) underlie the continuous epidemiological importance of these seafood as environmental reservoirs and a major predisposing factor of infection, potentially pathogenic Vibrio spp (Rippey, 1994; Aladese \& Enabulele, 2014; Oramadike \& Ogunbanwo, 2015).

Effective treatment of cholera infection is predicated on constant epidemiological surveillance of emergence of antibiotic-resistant strains. Table 6 showed pefloxacin, ofloxacin and ciprofloxacin as the antibiotics recommended for treatment. The efficacy of these fluoroquinolone drugs in this study is not unexpected as it is in agreement with documented study in the past (Aladese et al., 2015).

The presence of tetracycline-resistant strains in this study was not surprising. Amita et al. (2003) demonstrated the horizontal transfer of SXT genetic element among $V$. cholerae strains; this plasmid mediated transfer of SXT genetic element confers antibiotic resistanceespecially of tetracycline-to a recipient $V$. cholerae. The presence of antibiotic-resistant strains in this study further agrees with reported findings in the past (Ottaviani et al., 2001; Adeleye et al., 2008).

\section{CONCLUSION AND RECOMMENDATIONS}

Incessant and indiscriminate disposal of wastes, especially excreta, into water bodies in these creek communities should be discouraged. Efforts should also be intensified by local and regional authorities on the importance of personal and communal hygiene through public awareness on the dangers of $V$. cholerae and non-cholera Vibrio spp infections so as to forestall possible epidemics in these communities.

\section{REFERENCES}

Adeleye, A., Enyinnia, V., Nwanze, R., Smith, S. and Omonigbehin, E. (2008). Antimicrobial susceptibilty of potentially pathogenic halophilic Vibrio species isolated from seafoods in Lagos, Nigeria. African Journal of Biotechnology, 7 (20): 3791-3794.

Aladese M.A., Pondei J.O. and Enabulele O.I. (2015). Prevalence of Potentially Pathogenic Vibrio species in Sea-foods obtained from Markets in Lagos. International Journal of Basic Science and Technology, 1(1):39 - 42

Aladese, M.A. and Ariyo, A.B. (2017). Physico-Chemical Properties and Bacteria Qualities of hand-dug wells in Ebukuma, Rivers State Nigeria. International Journal of Basic Science and Technology, 3(1):59-72

Aladese, M.A. and Enabulele, O.I. (2014). Prevalence of potentially pathogenic Vibrio species from different locations of the Lagos lagoon. Nigerian Journal of Applied Science, 32: 127-136 
Amangabara, G.T. and Egenma, E. (2012). Groundwater quality assessment of Yenagoa and environs, Bayelsa State, Nigeria between 2010-2011. Resources and Environment, 2(2):20-29.

Amita, C.M., Thungapothra, Y., Nair, G.B. and Amit, G. (2003). Class I integron and SXT elements El Tor strains isolated before and after $1992 \mathrm{~V}$. cholerae 0139 outbreak in Calcutta, Indian. Emerging Infectious Diseases, 9(4): 500-502.

Canada Communicable Disease Report (1998). An advisory committee statement on tropical medicine and travel! Statement on oral cholera vaccine, 24(Act-5): 1-7.

Edokayi, C.A., Lawal, M.O., Okwok, N.A. and Ogunwemo, C.A. (2004). Physico-chemical and macrobenthic faunal characteristics of the Kuramo water, Lagos, southern Nigeria. African Journal of Aquatic Sciences 29 (2). 235-241

Elhadi, N., Radu, S., Chen, C. and NIshibudi, M. (2004). Prevalence of potentially pathogenic Vibrio species in the sea-foods marketed in Malaysia. Journal of Food Protection, 67(7): 1469-1475.

Faruque, S.M., Albert, M.J. and Mekalanos, J.J. (1998). Epidemiology, genetics and ecology of toxigenic Vibrio cholerae. Microbiology and Molecular Biology Reviews, 62(4):1301-1314.

Hutin, Y., Luby, S. and Paquet, C. (2003). A large cholera outbreak in Kano City, Nigeria: the importance of hand washing with soap and the danger of street-vended water. Journal of Water and Health, 1(1): 45-52.

Idika, I.N., Audu, R.A., Oyedeji, K.S., Iyanda, R. and Egbom, C.A. (2000). Investigation of different water sources as possible cause of cholera outbreak in Lagos, 1997. Journal of the Nigerian Association of Infection and Control, 3:111-117

Igbinosa, E.O., Obi, C.L. and Okoh, A.I. (2009). Occurrence of potentially pathogenic Vibrios in the final effluents of wastewater treatment facility in a rural community of the Eastern Cape Province of South Africa. Research Microbiology, 160:531-537.

Lawson, E.O. (2011). Physico-Chemical Parameters and Heavy Metal Contents of Water from the Mangrove Swamps of Lagos Lagoon, Lagos, Nigeria. Advances in Biological Research 5(1): 08-21.

Makino, K., Oshina, K., Shinagawa, H., Hattor, M. and Lida, T. (2003). Genome sequence of Vibrio parahaemolyticus: a pathogenic mechanism distinct of Vibrio cholerae. Lancet, 361(9359):743-749.

Miceli, G.A., Watkins, W.D. and Rippey, S.R. (1993). Direct plating procedure for enumerating Vibrio vulnificus in oysters (Crassostrea virginnia). Journal of Environmental Microbiology, 59(11):3619-3623.

Miller, J.F. (2003). Bacteriophage and the evolution of epidemic cholera. Infection and Immunity, 71:2981-2982.

Onyema, I.C. (2013). The Physico-Chemical Characteristics and Phytoplankton of the Onijedi Lagoon, Lagos. Nature and Science, 11(1):127-135.

Oramadike, C and Ogunbanwo, S.T. (2015). Prevalence and antimicrobial susceptibility of Vibrio parahaemolyticus isolated from seafoods in Lagos Lagoon Nigeria. Cogent Food \& Agriculture, 1:1-10

Ottaviani, D., Isidoro, B., Laura, M., Francesca, L., Antonio, C., Monica, G. and Giovoanni, S. (2001). Antimicrobial Susceptibility of Potential Pathogenic Halophilic Vibrio. International Journal of Antimicrobial Agents, 18(2): 135-140

Rippey, S.R. (1994). Infectious diseases associated with molluscan shell fish consumption. Clinical Microbiology Review, 7:419-425. 
Siddique, A. K., Salam, A., Islam, M. S., Akram, K., Majumdar, R. N., Zaman, K., Fronczak, N. and Laston, S. (1995). Why treatment centres failed to prevent cholera deaths among Rwandan refugees in Goma, Zaire. Lancet, 345:359-361.

Waldor, M. K. and Mekalanos, J. J. (1996). Lysogenic conversion by a filamentous bacteriophage encoding cholera toxin. Science, 272:1910-1914.

Waldor, M.K. and Raychaudhuri, D. (2000). Vibrio cholerae chromosomes: Treasure trove for cholera research. Nature, 406 (6795):469-70. 